\title{
Effect of Feeding Azolla Meal on Growth Performance of Mecheri Sheep
}

\author{
V. Sankar*, P. Senthilkumar, N. Sribalaji, P. Nalini, L. Arun and J. Muralidharan \\ Mecheri Sheep Research Station, Pottaneri-636453, Tamil Nadu Veterinary and Animal \\ Sciences University, Tamil Nadu, India \\ *Corresponding author
}

\section{A B S T R A C T}

Key w o r d s
Azolla, Mecheri
Sheep, Growth
performance

The study was conducted to evaluate the nutritional and feeding value of azolla meal in Mecheri lambs. For this study, twelve Mecheri female lambs at four month of age were randomly divided in to two equal groups of control and treatment. Experimental animals in control group were fed with basal diet comprising concentrate and roughage at the ratio of 40:60. In the treatment group 10 percent protein of concentrate mixture was replaced by supplementation of dried azolla meal on dry matter basis. Fortnightly body weight and dry matter intake was recorded for the period of three months. The results showed that there was no significant difference $(\mathrm{P}>0.05)$ between groups in dry matter intake, average daily gain and feed efficiency. Hence, it can be concluded that, dried azolla can replace ten per cent protein level in the concentrate feed without affecting the growth performance in Mecheri lambs.

\section{Introduction}

Sheep rearing is main livelihood of landless labourers of India. Due to of increase in production costs farmers need to incorporate cheap and locally available ingredients in sheep ration. Among plant protein sources, azolla is the fastest growing aquatic plant containing 20-35 per cent protein due to symbiotic relation with algae Anabaena azollae (Raja et al., 2012). The higher protein content attracts farmers to replace expensive conventional protein sources feed ingredients such as groundnut oilcake and other oil cakes sources (Khare et al., 2014). Apart from protein, azolla also contain essential amino acid (lysine) and minerals which are important for animal growth (Srinivas et al., 2012).

Anitha et al., (2016) reported that sun dried azolla can be used as livestock feed. The available works on azolla meal feeding were on fresh basis and work on feeding of sun dried azolla meal feeding is limited. Hence, the present study was undertaken to utilize the 
dried azolla as feed and replace the conventional concentrate feed to certain level in sheep ration.

\section{Materials and Methods}

This experiment was conducted at Mecheri Sheep Research Station (MSRS), Tamil Nadu Veterinary and Animal Sciences University (TANUVAS). Geographically this center is located at longitude of $77^{\circ} 56^{\prime} \mathrm{E}$, latitude of $11^{\circ} 45^{\prime} \mathrm{N}$ and altitude of about 650 feet above MSL. The local climate of the area is generally hot, semi-arid and tropical with an average rainfall of $831.4 \mathrm{~mm}$. Azolla was cultivated in HDPE 160 GSM thickness sheet pit covered with 60:40 shade net at MSRS, collected and dried under the shade for 48 hours.

The shade dried azolla was ground to reduce the particle size $(3 \mathrm{~mm})$ and used for experimental feeding. Twelve Mecheri female lambs at the age of four month were selected and randomly divided in to two equal groups in a completely randomized block deign of control and treatment groups. Experimental animals were acclimatized with experimental feeds for the period of 3 weeks before the start of growth trial. All the animals were dewormed and vaccinated as per the University recommended schedule. The control group was fed with basal diet comprising of concentrate and roughage (Sorghum stover) in the ratio of 40:60 for the period of three months.

In the treatment group 10 percent protein of concentrate mixture on dry matter basis was replaced by dried azolla meal. The chemical composition of feed and azolla were determined according to AOAC (2005). Measured quantity of concentrate mixture and azolla were fed to animals and sorghum fodder was offered adlibitium as per nutrient requirement (ICAR, 2013).
Water was made available throughout the period. Fortnightly body weight gain and dry matter intake was recorded and feed efficiency was calculated. The chemical of azolla, concentrate and sorghum stover are presented in table 1 . The data were processed and statistically analyzed as per the procedures of Snedecor and Cochran (1994).

\section{Results and Discussion}

The dry matter content of dried azolla meal was 88.0 percent. Similarly Gupta et al., (2018) observed 90 per cent DM and Navnath (2015) observed 89.91 Per cent. Azolla has higher fiber, ether extract, total ash and similar crude protein content compared to concentrate. The chemical composition of azolla estimated in the present study was similar to earlier reports. The minor variation may be due environmental factor and soil condition in which azolla cultivated (Sanginga and VanHove, 1989). The average DMI observed was $0.576 \pm 0.017$ and $0.547 \pm 0.013 \mathrm{~kg} /$ day in group I, and II respectively (Table 2 ).

There was no statistical $(\mathrm{P}>0.05)$ difference between the groups. The DMI was numerically lower in group II. The numerically lower dry matter intake may be due to high lignin and fiber content of azolla meal. It is in accordance with Ghodake et al., (2012) who reported that azolla feeding was effective only up to 15 percent in concentrate mixture due to high fibre content of azolla in Osmanbadi goats.

Animals in both groups grew linearly. Throughout the trail period control group lambs had numerically higher body weight than treatment group lambs. Final body weight gain was $5.93 \pm 0.63 \mathrm{~kg}$ in control group and $5.37 \pm 0.72 \mathrm{~kg}$ in treatment group over the period of 90 days. Since, there was no significant difference in body weight gain. 
It can be concluded that azolla could be effectively used to replace ten per cent protein from concentrate feed. The mean body weight gain $(\mathrm{kg})$ at fortnightly intervals during 90 days feeding trail are presented in Table 3.

The body weight changes between two groups were compared. The ADG was higher in group I $(65.93 \pm 0.632 \mathrm{~g})$ then in group II $(59.63 \pm 0.80 \mathrm{~g})$, but was no significant $(\mathrm{P}>0.05)$ difference between the groups. These result showed that replacement of ten per cent concentrate mixture with dried azolla meal did not have any adverse effect on growth of Mecheri lambs. The result was in accordance with Ghodake et al., (2012) in Osmanabadi kids who replaced 15 per cent concentrate mixture with azolla meal. The average feed conversion efficiency (FCE) value was also numerically higher in group II $(9.18 \pm 1.94)$ then in group I $(8.74 \pm 1.51)$ (Table 2).

There was no significant $(\mathrm{P}>0.05)$ difference between the groups. The decreased FCR in the azolla supplemented group was in accordance with the findings of Ahmed et al., (2016). The lower FCR in the present study may be due decreased dry matter intake. In total control group animals consumed 153.4 $\mathrm{kg}$ concentrate feed against $136.4 \mathrm{~kg}$ in azolla supplemented group during 90 days growth trial. Azolla feeding replaced $17 \mathrm{~kg}$ concentrate feed by $20 \mathrm{~kg}$ of dried azolla, fact shows that the concentrate replacement ratio was 0.85 .

Table.1 Chemical Composition (\%) of feed/feed ingredient

\begin{tabular}{|l|l|l|l|}
\hline Composition & Azolla & Concentrate & Sorghum \\
\hline Dry matter & 88.0 & 89.55 & 93.29 \\
\hline Crude Protein & 20.11 & 20.11 & 4.15 \\
\hline Crude Fibre & 30.62 & 7.96 & 32.81 \\
\hline Ether Extract & 4.17 & 3.2 & 1.33 \\
\hline Total Ash & 24.35 & 8.86 & 5.43 \\
\hline $\begin{array}{l}\text { Gross Energy } \\
\text { (Kcal/kg) }\end{array}$ & 3087 & 3730 & 3655 \\
\hline
\end{tabular}

Table.2 Mean dry matter intake (kg) and Feed conversion efficiency (kg) during 90 days feeding

\begin{tabular}{|l|c|c|c|c|}
\hline \multicolumn{1}{|c|}{ Fortnight } & control & Treatment & SEM & P- Value \\
\hline First & $7.00 \pm 0.31$ & $6.75 \pm 0.25$ & 0.195 & 0.536 \\
\hline Second & $7.85 \pm 0.24$ & $7.59 \pm 0.23$ & 0.164 & 0.447 \\
\hline Third & $8.35 \pm 0.22$ & $8.01 \pm 0.21$ & 0.154 & 0.296 \\
\hline Fourth & $9.00 \pm 0.25$ & $8.53 \pm 0.18$ & 0.163 & 0.156 \\
\hline Fifth & $9.56 \pm 0.29$ & $8.94 \pm 0.20$ & 0.172 & 0.070 \\
\hline Sixth & $10.11 \pm 0.22$ & $9.44 \pm 0.20$ & 0.177 & 0.053 \\
\hline Total body & $5.93 \pm 0.56$ & $5.37 \pm 0.72$ & 0.445 & 0.550 \\
\hline weight gain(kg) & & & & 0.205 \\
\hline DMI (kg) & $0.576 \pm 0.017$ & $0.547 \pm 0.013$ & 0.012 & 0.764 \\
\hline FCE (Feed/gain kg) & $8.74 \pm 1.51$ & $9.18 \pm 1.94$ & 1.180 & \\
\hline
\end{tabular}


Table.3 Mean growth rate (g/day) during 90 days feeding trail in different groups

\begin{tabular}{|c|c|c|c|c|}
\hline Fortnight & Control & Treatment & SEM & P Value \\
\hline Initial & $13.25 \pm 0.508$ & $13.25 \pm 0.503$ & 0.341 & 1.0 \\
\hline First & $14.46 \pm 0.439$ & $14.36 \pm 0.542$ & 0.333 & 0.888 \\
\hline Second & $15.73 \pm 0.425$ & $15.45 \pm 0.560$ & 0.338 & 0.695 \\
\hline Third & $16.68 \pm 0.400$ & $16.37 \pm 0.705$ & 0.389 & 0.704 \\
\hline Fourth & $17.61 \pm 0.404$ & $17.10 \pm 0.760$ & 0.418 & 0.542 \\
\hline Fifth & $18.45 \pm 0.491$ & $17.80 \pm 0.863$ & 0.483 & 0.527 \\
\hline Sixth & $19.18 \pm 0.542$ & $18.62 \pm 0.912$ & 0.513 & 0.605 \\
\hline Total gain in & $5.93 \pm 0.568$ & $5.37 \pm 0.720$ & 0.445 & 0.550 \\
\hline body weight & & & & 0.550 \\
\hline ADG(g/day) & $65.93 \pm 0.632$ & $59.63 \pm 0.801$ & 0.495 & \\
\hline
\end{tabular}

The replacement of concentrate with azolla at 10 per cent level showed similar performance in weaned Mecheri lambs. Hence these levels can be used as protein supplements to replace high cost concentrate feed in sheep ration.

\section{References}

Ahmed, H.A., Ganai, A.M., Beigh, Y.A., Sheikh, G.G, and Reshi, P.A. 2016. Performance of growing sheep on azolla based diets. Indian Journal of Animal Research. 50(5): 721-726.

Anitha, K.C., Rajeshwari Y.B., Prasanna, S.B and Shilpa Shree, J. 2016. Nutritive Evaluation of Azolla as Livestock Feed. Journal of Experimental Biology and Agricultural Sciences. 4(6): 670-674.

AOAC, 2005. Official methods of Analysis, 18th edition. Assoc. Off. Anal. Chem., Arlington, Verginia.

Ghodake, S..L.S., Fernandes A ..P., Darade, R.V and Zagade B. G. 2012. Effect of different levels of azolla meal on growth performance of Osmanabadi kids. Research Journal of Animal Husbandry and Dairy Sciences. 3(1):13-16.

Gupta, S.K., Chandra, Dey, R., Mondal, D and Shinde, K.P. 2018. Study of chemical composition and mineral content of sun dried Azolla pinnata.
Journal of Pharmacognosy and Phytochemistry 2018; 7(6): 1214-1216

ICAR. 2013. Nutritional Requirements of Sheep, Goat and Rabbit $2^{\text {nd }}$ ed. Indian Council of Agricultural Research, New Delhi. India.

Khare, A., Baghel, R.P.S., Gupta, R.S., Nayak, S., Khare, V. Paul, A., Sharma, R, Tomar, R and Singh, V.P. 2014. Milk production of indigenous cattle for supplement of mustard oil cake or aazolla meal (Azolla filliculoides). Livestock Research for Rural Development. 26(4):32-36.

Navnath, S.P. 2015. Effect of dietary levels of Azolla (Azolla pinnata) in broilers. M.Sc. Thesis.Dr. Balasaheb Sawant Konkan Krishi Vidyapeeth, Dapoli, Maharashtra.

Raja, W, Rathaur, P, John, S.A and Ramteke, R.W. 2012. Azolla an aquatic pteridoplyte with great potential. International Journal of Research in Biological Sciences. 2(2):68-72.

Sanginga, N and Van Hove, C. 1989.Amino acid composition of azolla as affected by strain and population. Plant \& Soil 117(2): 263-267.

Snedecor, C. W and Cochran, W. G. 1994 Statistical methods (6th edition) Iowa State University Press Anes USA.

Srinivas, K.D., Prasad, R.M.V., Kishor, K.R 
and Rao Ragharama, E. 2012. Effect of Azolla (Azolla pinnata) based concentrate mixture on nutrient utilization in buffalo calves. Indian Jouranal of Animal Research. 46(3): 268-271.

\section{How to cite this article:}

Sankar, V., P. Senthilkumar, N. Sribalaji, P. Nalini, L. Arun and Muralidharan, J. 2020. Effect of Feeding Azolla Meal on Growth Performance of Mecheri Sheep. Int.J.Curr.Microbiol.App.Sci. 9(05): 1945-1949. doi: https://doi.org/10.20546/ijcmas.2020.905.222 